\title{
Total Phenolic Content and Antioxidant Activity of Standardized Extracts from Leaves and Cell Cultures of Three Callistemon Species
}

\author{
Mohamed I. S. Abdelhady ${ }^{1,3 *}$, Amira Abdel Motaal'², Ludger Beerhues ${ }^{3}$ \\ ${ }^{1}$ Pharmacognosy Department, Faculty of Pharmacy, Helwan University, Cairo, Egypt; ${ }^{2}$ Pharmacognosy Department, Faculty of Pharmacy, \\ Cairo University, Cairo, Egypt; ${ }^{3}$ Institut für Pharmazeutische Biologie, Technische Universität Braunschweig, Braunschweig, Ger- \\ many. \\ Email: *mohibrahem@yahoo.com
}

Received September $26^{\text {th }}, 2010$; revised October 24 ${ }^{\text {th }}$, 2011; accepted November $5^{\text {th }}, 2011$.

\begin{abstract}
A comparative study was carried out with ethanolic (80\%) extracts from leaves and cell cultures of three Callistemon species, namely C. lanceolatus (CL), C. viridiflorous (CV), and C. comboynensis (CC). Cell suspensions of the three species were grown in liquid Murashige and Skoog (MS) medium $\left(100 \mathrm{ml}\right.$ ) supplemented with $0.9 \mathrm{mg} \cdot \mathrm{g}^{-1} \mathrm{kinetin}$ in combination with $1.1 \mathrm{mg} \cdot \mathrm{g}^{-1} \mathrm{NAA}$. The CL leaf extract was standardized to contain the highest amount of phenolics $\left(104 \pm 2.0 \mathrm{mg} \cdot \mathrm{g}^{-1}\right)$, followed by CC $\left(95.8 \pm 1.2 \mathrm{mg} \cdot \mathrm{g}^{-1}\right)$ and $C V\left(79.8 \pm 4.6 \mathrm{mg} \cdot \mathrm{g}^{-1}\right)$. On the other hand, cell cultures of $C V$ contained more phenolics $\left(14.9 \pm 0.6 \mathrm{mg} \cdot \mathrm{g}^{-1}\right)$ than those of the other two species, $C L$ and $C C$, which contained 12.2 \pm 0.16 and $9.12 \pm 0.16 \mathrm{mg} \cdot \mathrm{g}^{-1}$, respectively. Nevertheless, $C V$ leaf extract exhibited the highest antioxidant activity $(91.4 \% \pm 0.4 \%)$ at a concentration of $1000 \mu \mathrm{g} \cdot \mathrm{ml}^{-1}$, comparable to $100 \mu \mathrm{g} \cdot \mathrm{ml}^{-1}$ gallic acid $(90.8 \% \pm 1.5 \%)$.
\end{abstract}

Keywords: Callistemon, Phenolic Content, Antioxidant Activity, Callus, Cell Cultures

\section{Introduction}

The genus Callistemon (Myrtaceae) contains 34 species of beautiful evergreen shrubs and small trees. The majority of the Callistemon species is endemic to the more temperate regions of Australia, four species are found in New Caledonia and seven species have been introduced to India as ornamental trees [1]. They are commonly known as bottle brushes because of their cylindrical brushlike flowers resembling the traditional bottle brush.

C. lanceolatus, also named C. citrinus, is a wellknown shrub. Leaves of this plant are used as a tea substitute and have a refreshing flavor. Many phenolic compounds of this plant have been identified [2]. Due to the over-exploitation for its volatile oil and secondary metabolites, there is a great need to develop alternative strategies of conservation and industrial production of the bioactive compounds from this plant [3]. No reports of works were found concerning the other two species, $C$. viridiflorous and C. comboynensis.

In vitro cultures have the potential to form secondary metabolites and to exhibit bioactivity comparable to the original plant $[4,5]$. Cultured cells may serve industrial purposes, e.g. by immobilization of cells in a matrix for use in bioreactors. Besides the genetic potential of the donor plant for callus induction and growth of this callus in in vitro cultures, a medium containing sufficient nutrients, such as the preferred MS medium, is required [4].

Antioxidants play an important role in the prevention of human diseases. Antioxidant compounds may function as free radical scavengers, complexing agents for prooxidant metals, as well as reducing agents and quenchers of singlet oxygen formation [6-8]. Antioxidants are often used in oils and fatty foods to retard their autoxidation. Therefore, the importance of the search for natural antioxidants has greatly increased in recent years [9]. A focus is on plant-derived polyphenols because of their potential antioxidant and antimicrobial properties. Phenolic compounds exhibit considerable free-radical scavenging activity, which is determined by their reactivity as hydrogen- or electron- donating agents, their reactivity with other antioxidants and their metal chelating properties, as well as the stability of the resulting antioxidant-derived radicals $[10,11]$.

Our present work is a comparative study of leaves and 
cell cultures of three Callistemon species with respect to their potential as antioxidant agents in relation to their total content of phenolic compounds.

\section{Materials and Methods}

\subsection{Plant Material}

Plants of three Callistemon species, C. lanceolatus (CL), C. viridiflorus (CV), and C. comboynensis (CC), were collected from a cultivated area in Cairo, Alexandria Road, Egypt. They were kindly authenticated by Prof. Dr. M. Gebali (Plant Taxonomy and Egyptian Flora Department, National Research Center, Giza, Egypt). A voucher specimen of each was deposited at the herbarium of the Pharmacognosy Department, Faculty of Pharmacy, Helwan University, Cairo, Egypt.

\subsection{Calli and Cell Cultures}

Callus of CL was induced by a combination of 0.9 $\mathrm{mg} \cdot \mathrm{L}^{-1}$ kinetin and $1.1 \mathrm{mg} \cdot \mathrm{L}^{-1}$ NAA [12]. Calli of CV and CC were similarly induced (the detailed methodology will be published later on). Calli material ( $0.3 \mathrm{~g}$ each) were collected in the active growth phase (after the $15^{\text {th }}$ day of subculture) and placed in $250 \mathrm{ml}$ flasks containing $100 \mathrm{ml}$ liquid MS medium supplemented with 0.9 $\mathrm{mg} \cdot \mathrm{L}^{-1}$ kinetin in combination with $1.1 \mathrm{mg} \cdot \mathrm{L}^{-1} \mathrm{NAA}$. The resulting cell cultures of the three Callistemon species were incubated in a horizontal shaker at $100 \mathrm{rpm}$ and $25^{\circ} \mathrm{C}$ for 21 days.

\subsection{Preparation of the Extracts}

The three cell suspension cultures were aseptically filtered and the cells dried in a vacuum oven at $40^{\circ} \mathrm{C}$, together with the leaves of the three species. They were then macerated in $80 \%$ ethanol for two days, filtered and macerated for another two days. After filtration, they were concentrated under vacuum at $50^{\circ} \mathrm{C}$.

\subsection{Evaluation of the Antioxidant Activity}

Determination of the free radical scavenging activity of the different extracts was carried out using a modified quantitative DPPH (1,1-diphenyl-2-picrylhydrazyl; SigmaAldrich, St. Louis, MO, USA) assay [13]. Various concentrations of sample extracts in methanol were prepared $\left(1000,500,250\right.$, and $\left.100 \mu \mathrm{g} \cdot \mathrm{ml}^{-1}\right)$. Gallic acid was used as a positive control at concentrations of 100, 50, 25, and $10 \mu \mathrm{g} \cdot \mathrm{ml}^{-1}$. Blank samples were run using $1 \mathrm{ml}$ methanol in place of the test extract. One $\mathrm{ml}$ of $0.2 \mathrm{mM} \mathrm{DPPH}$ in methanol was added to $1 \mathrm{ml}$ of the test solution, or standard, plus $1 \mathrm{ml}$ of methanol for dilution and allowed to stand at room temperature in a dark chamber for $30 \mathrm{~min}$. The change in colour from deep violet to light yellow was then measured at $517 \mathrm{~nm}$. Inhibition of free radical in percent (I\%) was calculated according to the following equation: $\mathrm{I} \%=[(\mathrm{A} 0-\mathrm{A} 1) / \mathrm{A} 0] \times 100$, with $\mathrm{A} 0$ being the absorbance of the control reaction (containing all reagents except for the extract) and A1 the absorbance of the extract. Measurements were carried out in triplicates.

\subsection{Determination of Total Phenolic Content}

A spectrophotometric method after MacDonald [14] was adopted for the determination of total polyphenols in the prepared extracts. Folin-Ciocalteu reagent from Merck (Darmstadt, Germany) was used and a standard calibration curve was prepared using different concentrations of gallic acid in methanol $\left(0.025-0.400 \mathrm{mg} \cdot \mathrm{ml}^{-1}\right)$. Cell culture and leaf extracts were prepared in methanol at a concentration of $0.06 \mathrm{~g} / 3 \mathrm{ml}$ and $0.06 \mathrm{~g} / 20 \mathrm{ml}$, respectively. Absorbance was measured at $765 \mathrm{~nm}$. For each sample, three replicate assays were performed. The total phenolic content was calculated as gallic acid equivalent (GAE) by the following equation: $\mathrm{T}=\mathrm{C} \times \mathrm{V} / \mathrm{M} . \mathrm{T}$ is the total phenolic content in $\mathrm{mg} \cdot \mathrm{g}^{-1}$ of the extracts as GAE, $C$ is the concentration of gallic acid established from the calibration curve in $\mathrm{mg} \cdot \mathrm{ml}^{-1}, \mathrm{~V}$ is the volume of the extract solution in $\mathrm{ml}$ and $\mathrm{M}$ is the weight of the extract in $\mathrm{g}$.

\section{Results and Discussion}

\subsection{Phenolic Content of the Extracts}

Ethanolic (80\%) extracts from the leaves and cell cultures of the three Callistemon species were standardized for their contents of phenolic compounds. The calibration curve showed linearity for gallic acid in the range of $25-400 \mu \mathrm{g} \cdot \mathrm{ml}^{-1}$, with a correlation coefficient (R2) of 0.999 (Figure 1). Leaves of CL contained the highest content of phenolics $\left(104 \pm 2.0 \mathrm{mg} \cdot \mathrm{g}^{-1}\right)$, followed by CC $\left(95.8 \pm 1.2 \mathrm{mg} \cdot \mathrm{g}^{-1}\right)$ and $\mathrm{CV}\left(79.8 \pm 4.6 \mathrm{mg} \cdot \mathrm{g}^{-1}\right)$. On the other hand, cell cultures of $\mathrm{CV}$ were standardized to contain more phenolics $(14.9 \pm 0.6)$ than the cell suspensions of the other two species, CL and CC, which contained $12.2 \pm 0.16$ and $9.12 \pm 0.16 \mathrm{mg} \cdot \mathrm{g}^{-1}$, respectively (Figure 2).

\subsection{Antioxidant Activity of the Extracts}

It is well known that there is a strong relationship between total phenol content and antioxidant activity, as phenols possess strong scavenging ability for free radicals due to their hydroxyl groups. Therefore, the phenolic content of plants may directly contribute to their antioxidant action $[11,15,16]$.

The standardized Callistemon extracts were assessed for their capacity to scavenge DDPH free radical along with gallic acid as a positive control. The antioxidant activity data are presented as percent of free radical inhi- 


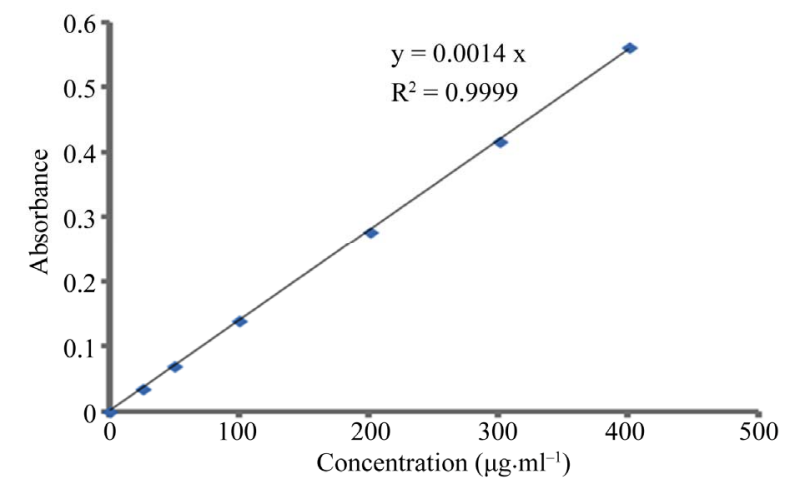

Figure 1. Standard calibration curve of gallic acid at concentrations of $25,50,100,200,300$ and $400 \mu \mathrm{g} \cdot \mathrm{ml}^{-1}$. Spectrophotometric detection was at $765 \mathrm{~nm}$.

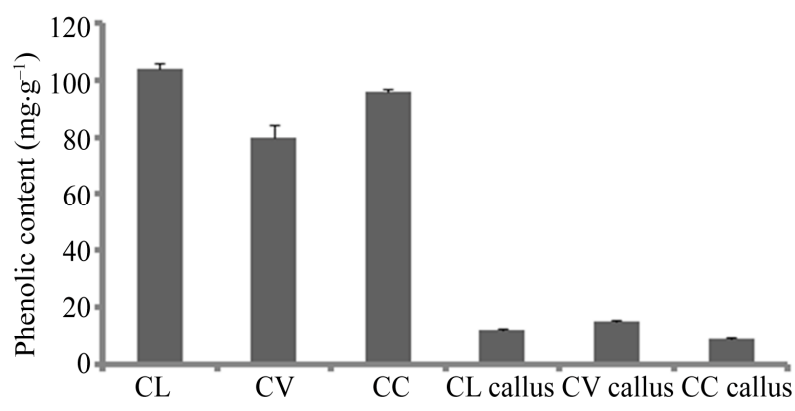

Figure 2. Total phenolic content of leaf and cell culture extracts from three Callistemon species determined by the Folin-Ciocalteu assay and calculated as GAE in $\mathrm{mg} \cdot \mathrm{g}^{-1} \mathbf{e x}-$ tract based on dry weight. Results are the average of triplicates \pm SD.

Table 1. Antioxidant activity of Callistemon leaf and cell culture extracts assayed by the DPPH assay.

\begin{tabular}{ccccccccc}
\hline $\begin{array}{c}\text { Conc. of extract } \\
\boldsymbol{\mu g} / \mathbf{m I}\end{array}$ & $\begin{array}{c}\boldsymbol{C L} \\
\text { leaves }\end{array}$ & $\begin{array}{c}\boldsymbol{C V} \\
\text { leaves }\end{array}$ & $\begin{array}{c}\boldsymbol{C C} \\
\text { leaves }\end{array}$ & $\begin{array}{c}\boldsymbol{C L} \\
\text { cultures }\end{array}$ & $\begin{array}{c}\boldsymbol{C V} \\
\text { cultures }\end{array}$ & $\begin{array}{c}\boldsymbol{C C} \\
\text { cultures }\end{array}$ & $\begin{array}{c}\text { Conc. of standard } \\
\boldsymbol{\mu g} / \mathbf{m l}\end{array}$ & $\begin{array}{c}\text { Gallic acid } \\
1000\end{array}$ \\
$73.5 \pm 3.2$ & $91.4 \pm 0.4$ & $74.4 \pm 0.3$ & $50.7 \pm 0.2$ & $71.1 \pm 0.4$ & $47.3 \pm 1.9$ & 100 & $90.8 \pm 1.5$ \\
500 & $67.3 \pm 0.2$ & $78.4 \pm 0.2$ & $66.9 \pm 0.9$ & $41.7 \pm 1.4$ & $68.4 \pm 0.2$ & $44.4 \pm 0.3$ & 50 & $83.7 \pm 0.6$ \\
250 & $60.3 \pm 2.0$ & $75.4 \pm 0.4$ & $57.8 \pm 0.7$ & $38.3 \pm 0.4$ & $53.5 \pm 0.2$ & $35.3 \pm 0.2$ & 25 & $76.3 \pm 0.2$ \\
100 & $48.9 \pm 3.7$ & $57.4 \pm 0.4$ & $56.3 \pm 0.3$ & $35.9 \pm 0.8$ & $46.7 \pm 0.2$ & $34.1 \pm 0.1$ & 10 & $65.4 \pm 0.1$ \\
\hline
\end{tabular}

Activity is expressed as inhibition of free radical in percent, I\% \pm SD $(n=3)$. Leaf and cell culture extracts were tested at 1000, 500,250 and $100 \mu \mathrm{g} \cdot \mathrm{ml}^{-1}$ and the positive control (gallic acid) at 100, 50, 25 and $10 \mu \mathrm{g} \cdot \mathrm{ml}^{-1}$.

bition in Table 1. The ethanolic (80\%) extracts of the leaves of $\mathrm{CV}$ exhibited pronounced antioxidant activity $(91.4 \% \pm 0.4 \%)$ at a concentration of $1000 \mu \mathrm{g} \cdot \mathrm{ml}^{-1}$, comparable to $100 \mu \mathrm{g} \cdot \mathrm{ml}^{-1}$ gallic acid $(90.8 \% \pm 1.5 \%)$, although its phenolic content was less than that of CL and CC (Figure 2). Furthermore, extracts of CV cell cultures showed antioxidant activity $(71.1 \% \pm 0.4 \%)$ comparable to that of leaf extracts of CL and CC at $1000 \mu \mathrm{g} \cdot \mathrm{ml}^{-1}$, even though their phenolic contents were approximately 7-fold that of CV cell cultures (Figure 2). It was previously reported that non-phenolic antioxidants might also contribute to the antioxidant activity of plant extracts $[17,18]$. Thus, compounds other than phenolics might be responsible for the pronounced antioxidant activity observed with CV extracts, which requires further investigation. Polyphenolic compounds are also believed to have chemopreventive and suppressive activities against cancer cells by inhibition of metabolic enzymes involved in the activation of potential carcinogens or arresting the cell cycle [19]. Nevertheless, a compound with strong antioxidant potential can also contribute to DNA protection and prevent apoptosis [20]. Further studies are therefore required to detect potential anticancer activities of the extracts reported here.

\section{Acknowledgements}

Part of this research work was funded by the DFG (Deutsche Forschungs Gemeinschaft).

\section{REFERENCES}

[1] P. C. Kanjilal and A. Das, "Flora of Assam,” Omsons Publications, New Delhi, 1992.

[2] I. I. Mahmoud, F. A. Moharram, M. S. Marzouk, M. W. Linscheid and M. I. Salch, "Polyphenolic Constituents of Callistemon Lanceolatus Leaves,” Pharmazie, Vol. 57, No. 7, 2002, pp. 494-496.

[3] R. K. Sharma, R. Kotoky and P. R. Bhattacharya, "Volatile Oil from the Leaves of Callistemon lanceolatus D.C. Grown in Northeastern India,” Flavonoid and Fragrance Journal, Vol. 21, No. 2, 2006, pp. 239-240. doi.org/10.1002/ffj.1564

[4] M. R. Ahuja, D. A. Evens, W. R. Sharp and P. J. Ammirato, "Handbook of Plant Cell Culture," Macmillan, New York, 1986, pp. 626-651.

[5] A. Parsaeimehr, E. Sargsyan and K. Javidnia, “A Comparative Study of the Antibacterial, Antifungal and Antioxidant Activity and Total Content of Phenolic Compounds of Cell Cultures and Wild Plants of Three Endemic Species of Ephedra," Molecules, Vol. 15, No. 3, 2010, pp. 1668-1678. doi.org/10.3390/molecules15031668 
[6] E. A. Bell, "The Possible Significance of Secondary Compounds in Plant,” In: E. A. Bell and B. V. Charlwood, Eds., Secondary Plant Products, Springer-Verlag, New York, 1980, pp.11-21.

[7] F. Constable, O. L. Gamborg, W. G. W. Kurz and W. Steek, "Production of Secondary Metabolites in Plant Cell Cultures,” Planta Medica, Vol. 25, 1974, pp. 158-165. doi.org/10.1055/s-0028-1097926

[8] C. A. Rice-Evans, N. J. Miller and G. Paganaga, "Antioxidant Properties of Phenolic Compounds," Trends in Plant Science, Vol. 2, No. 4, 1997, pp. 152-159. doi.org/10.1016/S1360-1385(97)01018-2

[9] C. Zollman and A. Vickers, "Complementary Medicine and the Patient,” British Medical Journal, Vol. 319, 1999, pp. 1486-1494.

[10] M. K. Ang-Lee, S. J. Moss and C. S. Yuan, "P.P. Herbal Medicines and Preoperative Care," The Journal of the American Medical Association, Vol. 286, No. 2, 2001, pp. 208-216. doi.org/10.1001/jama.286.2.208

[11] A. Wojdylo, J. Oszmianski and R. Czemerys, “Antioxidant Activity and Phenolic Compounds in 32 Selected Herbs,” Food Chemistry, Vol. 105, No. 3, 2007, pp. 940949. doi.org/10.1016/j.foodchem.2007.04.038

[12] R. S. D. Paul Raj, S. M. Morais and K. Gopalakrishnan, "In Vitro Propagation of Callistemon citrinus. L.," Indian Journal of Science and Technology, Vol. 3, No. 1, 2010, p. 67.

[13] L. L. Mensor, F. S. Menezes, G. G. Leitão, A. S. Reis, T. C. dos Santos, C. S. Coube and S. G. Leitão, "Screening of Brazilian Plant Extracts for Antioxidant Activity by the Use of DPPH Free Radical Method," Phytotherapy Research, Vol. 15, No. 2, 2001, pp. 127-130. doi.org/10.1002/ptr.687

[14] S. Mcdonald, P. D. Prenzler, M. Autolovich and K. Ro- bards, "Phenolic Content and Antioxidant Activity of Olive Oil Extracts,” Food Chemistry, Vol. 73, No. 1, 2001, pp. 73-84. doi.org/10.1016/S0308-8146(00)00288-0

[15] A. Bendini, L. Cerretani, L. Pizzolante, T. Gallina-Toschi, F. Guzzo, S. Ceoldo, A. M. Marconi, F. Andreetta and M. Levi, "Phenol Content Related to Antioxidant and Antimicrobial Activity of Passiflora Spp. Extracts,” European Food Research and Technology, Vol. 223, No. 1, 2006, pp. 102-109. doi.org/10.1007/s00217-005-0150-7

[16] A. Dlugosz, J. Lembas-Bogaczyk and E. Lamer-Zarawska, "Antoxid Increases Ferric Reducing Antioxidant Power (FRAP) even Stronger than Vitamin C,” Acta Poloniae Pharmaceutica, Vol. 63, 2006, pp. 446-448.

[17] R. Harish and T. Shivanandappa, "Antioxidant Activity and Hepatoprotective Potential of Phyllanthus niruri," Food Chemistry, Vol. 95, No. 2, 2006, pp. 180-185. doi.org/10.1016/j.foodchem.2004.11.049

[18] N. Hassimotto, M. Genovese and F. Lajolo, “Antioxidant Activity of Dietary Fruits, Vegetables, and Commercial Frozen Fruit Pulps,” Journal of Agricultural and Food Chemistry, Vol. 53, No. 8, 2005, pp. 2928-2935. doi.org/10.1021/jf047894h

[19] D. J. Newman, G. M. Gragg, S. Holbeck and E. A. Sausville, "Natural Products as Leads to Cell Cycle Pathway Targets in Cancer Chemotherapy,” Current Cancer Drug Targets, Vol. 2, No. 4, 2002, pp. 279-308. doi.org/10.2174/1568009023333791

[20] V. Rajkumar, H. Guha and R. A. Kumar, "Antioxidant and Anticancer Potentials of Rheum Emodi Rhizome Extracts,” Food and Chemical Toxicology, Vol. 49, No. 2, 2011, pp. 363-369. 